$\mathrm{A} \int_{\cos } \mathrm{H}$

Article history :

Received : 12.12.2014

Accepted : 31.05.2015
THEASIAN JOURNAL OF HORTICULTURE

Volume 10 | Issue 1 | June, 2015 | 184-186

Visit us -www.researchjournal.co.in

\title{
Effect of PGR, chemicals and plant extract on seed germination and seedling growth of custard apple (Annona squamosa)
}

Members of the Research Forum

Associated Authors:

${ }^{1}$ Department of Horticulture, K.K. Wagh College of Agriculture,

NASHIK (M.S.) INDIA

${ }^{2}$ Department of Agricultural Economics, K.K. Wagh College of Agriculture, NASHIK (M.S.) INDIA

Email : rejeswari_raundal@

rediffmail.com

Author for correspondence :

ARCHANA C. JADHAV

Department of Horticulture, K.K.

Wagh College of Agriculture,

NASHIK (M.S.) INDIA

Email : archanaorganic@gmail.com

\section{ARCHANA C. JADHAV, Y.L. BHAGURE ${ }^{1}$ AND RAJESWARI M. RAUNDAL ${ }^{2}$}

ABSTRACT : The aim of this study was to evaluate the effect of PGR, chemicals and plant extract on seed germination and seedling growth of custard apple. The results of present investigation clearly showed the significant differences with respect to effect of seed soaking

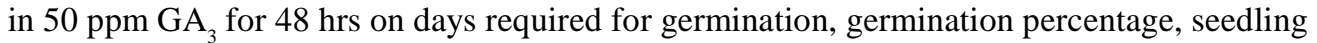
height, stem diameter and number of leaves per seedling of custard apple. As these results are based on single trail extensive trials may be conducted to confirm the findings. Thus, it can be concluded that seed treatment of $\mathrm{GA}_{3}$ at $50 \mathrm{ppm}$ for $48 \mathrm{hrs}$ was helpful to get higher germination and seedling growth of custard apple.

KEY WORDS : Annona squamosa, Custard apple, GA, $\mathrm{A}_{3}$ PGR, PPM, Seed germination

HOW TO CITE THIS ARTICLE : Jadhav, Archana C., Bhagure, Y.L. and Raundal, Rajeswari M. (2015). Effect of PGR, chemicals and plant extract on seed germination and seedling growth of custard apple (Annona squamosa). Asian J. Hort., 10(1) : 184-186. 